$1-1-1984$

\title{
Four Leagues of Pecos: A Legal History of the Pecos Grant, 1800 - 1933
}

\author{
G. Emlen Hall \\ University of New Mexico - School of Law, hall@law.unm.edu
}

Follow this and additional works at: https://digitalrepository.unm.edu/law_facbookdisplay

Part of the Law Commons

\section{Recommended Citation}

Hall, G. Emlen. "Four Leagues of Pecos: A Legal History of the Pecos Grant, 1800 - 1933." (1984): 367 pages.

https://digitalrepository.unm.edu/law_facbookdisplay/2

This Book is brought to you for free and open access by the School of Law at UNM Digital Repository. It has been accepted for inclusion in Faculty Book Display Case by an authorized administrator of UNM Digital

Repository. For more information, please contact amywinter@unm.edu.

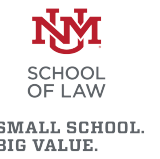




\section{Four Leagues \\ of Pecos}

A Legal History of the Pecos Grant, 1800-1933

G. Emlen Hall

University of New Mexico Press Albuquerque 
Library of Congress Cataloging in Publication Data

Hall, G. Emlen, 1942-

Four leagues of Pecos.

(New Mexico land grant series)

Includes bibliographical references and index.

1. Pueblo Indians-Claims-History. 2. Pueblo Indians

- Land tenure-History. 3. Indians of North America-

New Mexico-Claims-History. 4. Indians of North

America-New Mexico-Land tenure-History. 5. Land

grants-New Mexico-History. I. Title. II. Series.

KFN4105.5.P9H34 $1984 \quad 346.73^{\prime} 08997$

ISBN 0-8263-0710-8 $\quad 347.3068997$

$83-23505$

A portion of Chapter 1 appears in an expanded version as "Mexican Liberals and the Pueblo Indians, 1821-1829," by G. Emlen Hall and David J. Weber, New Mexico Historical Review, V. 4 No. 1 (January 1984): 5-32.

(C) 1984 by the University of New Mexico Press. All rights reserved. Manufactured in the United States of America.

ISBN 0-8263-0710-8

Library of Congress Catalog Card Number 83-23505.

Second printing, 2002. 


\section{Illustrations}

Frank Springer 139

Antonio Joseph 139

T. B. Catron 140

Donaciano Vigil 140

Grant, with signatures of Vigil and Pino 141

Herbert J. Hagerman 141

Stephen B. Elkins 141

Aerial photograph of the ciénaga of Pecos, 1953142

Maps

1 The Pecos Pueblo Grant and Its Environs viii

2 Pecos Pueblo Meets Its Neighbors, 1815-18 2

3 The Pecos Pueblo Grant in 1825 Under Mexican Rule 64

4 The Pecos Pueblo Grant on the Eve of the 1877 Joseph Decision 145

5 The Pecos Pueblo Grant in 1915199

6 The Pueblo Lands Board Finishes with the Pecos Pueblo Grant 272 


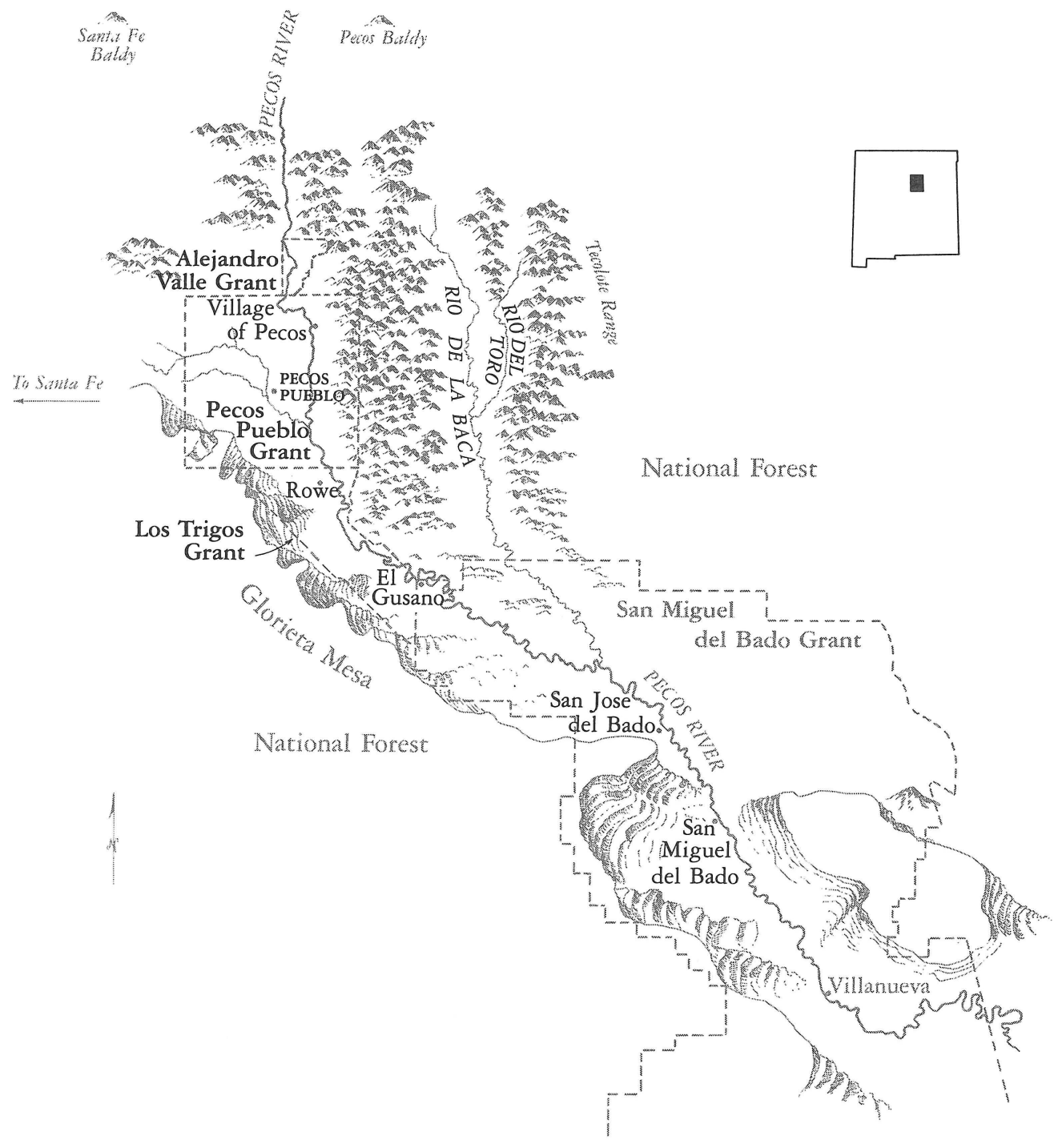

MAP 1. The Pecos Pueblo Grant and Its Environs

Except for the relatively small, 573 acre Alejandro Valle Grant, the Pecos Pueblo Grant lay closer to the headwaters of the Pecos River than any other grant originating under Spain or Mexico. Formal settlement of the area east of the Rio Grande Basin did not begin until 1794 with the making of the huge 350,000 acre San Miguel del Bado Grant. By 1803 the Hispanic towns of San Miguel del Bado and San Jose del Bado had taken root. By 1815 government officials had completed the legal creation of the 9,647 acre Los Trigos Grant, immediately south of the Pecos Pueblo Grant. 


\section{Foreword}

Four Leagues of Pecos is a historical study of the legal relationships between man and land in Pecos, New Mexico. Control of land and water was the foundation of the economic and social order in New Mexico, and consequently uncertain land tenure caused enormous confusion, social conflict, and, at times, violent upheaval. This study of land tenure- the laws and customs governing landholding and use as well as the application of the principles-enables us to understand the human need to occupy land and exploit the earth's resources to secure a livelihood.

Land tenure has long been a crucial issue in New Mexico. From an ecological perspective, this may be attributed to the meager resources of its semiarid land, particularly the limited amount of irrigable land for farming found in the narrow river valleys. During periods of rapid population growth, these scarce natural resources engendered intense, and frequently, bitter competition among New Mexico's residents. It is this struggle for land that every student seeking to understand the region must come to appreciate.

New Mexico's multiethnic heritage under three sovereigns-the colonial Spanish Empire, the Mexican Republic, and the United Statesdefies full understanding until the evolution of land tenure is comprehended. An adequate synthesis of this vital dimension of New Mexican history can only be written after a number of detailed local studies, which reveal the range of geographic, ecologic, and social variations in land tenure, have been made. To date, the only such studies we have are those devoted to a single region, the territory encompassed by the Maxwell land grant. This second volume in the New Mexico Land Grant Series is the only study ever to trace an active land grant 
problem through three sovereigns. The sources are drawn mainly from primary and untapped documents held in a variety of locales in this country that have materials from Spain, Mexico, and the United States. These sources are richly supplemented by Pecos oral history.

Four Leagues of Pecos is local history at its finest. It is the product of the author's decade-long residence in Pecos, coupled with considerable practical experience with New Mexico's land and water law as an attorney in the State Engineer's Office in New Mexico. G. Emlen Hall, the author, conveys a vivid sense of the land-the special place that is Pecos-as well as the many subtle nuances of the Spanish, Mexican, and United States's governmental and legal regimes which have, in sequence, attempted to sanction and regulate man's presence on the Pecos Pueblo grant lands.

Only Hall could have written this book. Continuing a remarkable New Mexican tradition, Hall is an Eastern-trained lawyer whose fascination with the events and people in the state's past inspired him to take up the historian's pen. I will venture to predict, and I believe the reader will agree, that Em Hall is destined to achieve a place among the distinguished group of lawyer-historians that includes William A. Keleher, L. Bradford Prince, and Ralph E. Twitchell.

Hall is obviously at home with the massive body of administrative and legal records pertaining to Pecos. Thus, he is able to guide the reader skillfully through the labyrinth that is the grant's legal history. In the end, perhaps the greatest achievement of this minutely detailed, exhaustive examination of the interminable struggle for the Pecos grant lands is that Hall conveys more completely and profoundly than ever before the tremendous social, political, and economic costs incurred by New Mexico as a consequence of uncertain or clouded land titles.

This study is, however, much more than local history, and it will be of interest to scholars and other readers from several broad perspectives. For students of Latin American land and society, the volume provides a much needed study of regional land tenure on the far northern frontier of New Spain and, after 1821, the Mexican Republic. As a proper study should, it sets the local land history in the wider context of New World Hispanic land tenure laws and practices and, in particular, the consequences of the land reforms instituted by the Spanish Cortes of 1810-13. The volume will complement the considerable literature on the latifundio or the large agrarian estate in Latin America, represented by the bacienda on the northern frontier of New Spain. This 
book bears comparison with William Taylor's history of land and society in colonial Oaxaca. Along with Taylor's work and other regional land tenure studies yet to come, the Four Leagues of Pecos will help to broaden our understanding of an enduring theme in Latin American history: the centuries-long contest between Indian and Hispano, pueblo (landholding community) and bacienda, and the minifundio and the latifundio for control over scarce land resources.

In a regional frame of reference, this study is an important new work on Hispanic land grants. It treats the careers of the principal land speculators who began to have an impact on New Mexico land grants during the Mexican Period. In doing so, it also outlines the little understood role of the Mexican diputación in land administration.

Of equal significance is the treatment of the colossal confusion in land administration that reigned throughout the United States territorial period and the untangling of financial deals by a group of early New Mexico figures who were able to profit personally from this disgraceful state of affairs. Operating during the 1850s and 1860s, this group might be called the "early Santa Fe land grant ring," for it preceded Thomas B. Catron and his cronies who became famous only during the latter decades of the nineteenth century.

Finally, the book merits special attention as a study of Hispanic and, later, Anglo encroachment on Pueblo grant lands. Myra Ellen Jenkins has been the leading historian in this field, and. Hall has been able to build successfully on the fine foundations she and others have laid. The closely intertwined question of the Pueblos' legal status under American rule-were they to be considered full citizens or wards of the government-is also extensively treated. While ever mindful of his principal subject, Pecos, the author skillfully weaves together the wider legal and political forces at play, highlighted by a detailed review of the famous Joseph decision in 1877 and culminating with an analysis of the Pueblo Lands Board, which carried out its work in the 1920s. Students of Pueblo Indian history will be grateful for this incisive analysis of a vast and difficult subject.

A few words of caution to the reader who is not well acquainted with New Mexico's Hispanic land grant history are in order. As is to be expected, this history relies mainly on the study of the formal administrative and legal records of the Pecos Pueblo grant lands. However, during the nineteenth century the vast majority of those who claimed and settled on the grant were illiterate, so customary, informal 
land tenure practices prevailed over codified law. Also a large number of land transactions most likely took place without the creation of a formal written record. Under Spanish law, in fact, land transfers could be executed verbally. These customary practices endured long after the end of the Spanish colonial and Mexican administrations. Thus, the whole history of Pecos land tenure can never be retrieved.

Although the Pecos story holds much in common with the history of the other Pueblo land grants as well as the non-Indian grants, it was also quite unique in many respects. It always presented special problems to those who attempted to claim it as well as to the many government officials, judges, and others responsible for regulating land and settling land disputes in New Mexico. By no means have all Hispanic land grants entailed conflict with Pueblo land claims. Further, varying and, in some instances, entirely different social, economic, and political forces were present in other land grant histories. Thus, the reader must be careful not to over generalize. (For a comprehensive overview of the Hispanic land grants of the Upper Rio Grande region, the first volume in this series, Mercedes Reales by Victor Westphall, is highly recommended.)

With these words of caution well taken, I commend this remarkable study to the reader. He will find in the pages that follow a most engrossing story presented skillfully and elegantly. Em Hall brings clarity to an incredibly complex legal history and, through his penetrating analysis of Pecos, provides many new insights into the nature of the relationships between man, land, and society in New Mexico.

John R. Van Ness Series Editor

December 15, 1983

Ardmore, Pennsylvania 